Please do not remove this page

RMIT

UNIVERSITY

\title{
Authentic learning for pre-service teachers in a technology-rich environment
}

Latham, Gloria; Carr, Nicola

https://researchrepository.rmit.edu.au/esploro/outputs/9921858252801341/filesAndLinks?institution=61RMIT_INST\&index=null

Latham, G., \& Carr, N. (2012). Authentic learning for pre-service teachers in a technology-rich environment. Journal of Learning Design, 5(1), 32-42.

https://researchrepository.rmit.edu.au/discovery/fulldisplay/alma9921858252801341/61RMIT_INST:Resea rchRepository

Document Version: Published Version

Repository homepage: https://researchrepository.rmit.edu.au

(C) 2012 Queensland University of Technology

Downloaded On 2023/04/27 01:36:17 +1000 
Thank you for downloading this document from the RMIT Research Repository.

The RMIT Research Repository is an open access database showcasing the research outputs of RMIT University researchers.

RMIT Research Repository: http://researchbank.rmit.edu.au/

\section{Citation:}

Latham, G and Carr, N 2012, 'Authentic learning for pre-service teacherrs in a technology-rich environment', Journal of Learning Design, vol. 5, no. 1, pp. 32-42.

See this record in the RMIT Research Repository at: http://researchbank.rmit.edu.au/view/rmit:16790

Version: Published Version

Copyright Statement: (c) 2012 Queensland University of Technology

Link to Published Version:

https://www.jld.edu.au/article/view/101/93

\section{PLEASE DO NOT REMOVE THIS PAGE}




\title{
AUTHENTIC LEARNING FOR PRE-SERVICE TEACHERS IN A TECHNOLOGY-RICH ENVIRONMENT
}

\author{
Gloria Latham \\ School of Education RMIT University, Australia \\ gloria.latham@rmit.edu.au \\ Nicky Carr \\ School of Education RMIT University, Australia \\ nicky.carr@rmit.edu.au
}

\begin{abstract}
This paper shares the findings from a three year Participatory Action Research Study around the selection, implementation and effectiveness of educational technologies for enhancing learning in a Teacher Education subject for second year pre-service primary teachers. The innovative ProjectBased subject is described using a critical lens. The paper will share how two lecturers and their students explored their changing roles as teachers and learners and the tensions that emerged between their beliefs about student centered, authentic learning and the role of technology. It will explore the ways the technological innovations began to reshape and inform thinking about teaching and learning practices.
\end{abstract}

\section{Keywords}

Teacher education, transformative pedagogies, ICT, disruption

\section{Introduction}

Universities appear to have lost their way. Non-attendance at lectures is an ongoing problem occurring across countries, universities and disciplines (Gosper et al., 2008; Gump, 2006; Nicholl $\&$ Timmins, 2005). To address the concern of low attendance and lack of motivation, the Association of Universities and Colleges of Canada held a two-day summit in March 2011 in Halifax, Nova Scotia on transforming undergraduate education in Canada. Many delegates spoke of the need to foster innovation in teaching and subject design, for example, "Part of what is happening is that students are afraid to take risks, they are absolutely driven by the tyranny of marks" (Ramona Lumpkin, President of Mount Saint Vincent University).

Salopek (2003) argued that Generation Y or "digital natives" as Prensky (2001) called them prefer a different approach to learning. As visual learners, they are attracted to graphics, animation and video; they are active learners as opposed to passive; they can have a relatively short attention span and the boundaries between work and play are increasingly blurred. As well, Generation Y expect technology to be a big part of their learning experience. Presently many university programs have not succeeded in integrating innovative approaches to learning with the use of technology into their teaching and into students' learning (Brown \& Warschauer, 2006; Fishman \& Davis, 2006; Otero et al. 2005). Teacher education students, whilst skilled at using technology in their personal lives, need to have a better understanding of how technology can support student learning (Angeli \&Valanides, 2009). Numerous studies provide evidence that students in programs that integrate and model the use of technology perform better (Drake \& Burns, 2004; Nolan \& 
McKinnon, 2003; Otero et al., 2005). Teacher education institutions are being urged to model the integration of technology and student-centered pedagogies to their students (Ertmer \& OttenbreitLeftwich, 2010).

This paper describes the experiences of two teacher educators who attempted to foster innovation and risk taking in a technology-enriched subject to engage Generation Y learners. It explores their changing roles as teachers and the tensions that emerged between their intended and enacted practices about student-centered, authentic learning and the role of technology.

\section{The Innovation}

The subject emerged in response to a perceived need from both anecdotal and Course Experience Survey data to address issues of student disengagement in the second year of a four year Bachelor of Education primary program. The following four aims are central to the subject and the research project.

- To engage students in their learning.

- To disrupt the norms of traditional schooling and demonstrate risk taking, rather than further traditional transmissive models of teaching.

- To integrate technology in ways that were purposeful, student-centered and authentic, and in ways that fostered exploration and discovery (Jonassen, Howard, Marra \& Crismond, 2008).

- To enable students to transform ideas and skills to their own teaching practices

Interested staff from a range of disciplines (literacy, maths, science and ICT) met together to plan for this innovation. What emerged was a blended learning environment - an extended face-to-face role-play over an entire semester supported by an online environment where a mystery needed to be solved.

Utilising and building on what we knew about drama, cooperative learning, digital gaming and project based learning, we fashioned three different mysteries over the three year project ${ }^{1}$. The 150 students and staff who participated in the subject each year wore two hats - one as a learner, immersed in the mystery, the other as practitioner, reflecting on the pedagogical approaches modelled throughout the mystery. Each student and staff member was allocated a character's role to adopt as members of a Task Force. Each student character had one of five occupations related to the content of the mystery. Teams were made up of at least one member of each occupation in an attempt to foster students' abilities to see situations from multiple perspectives. Each team was part of a central Task Force working collaboratively to solve the mystery. Our intent was to foster collaboration rather than competition amongst the teams of students, so varied pieces of "evidence" were provided to some team members but not others. The evidence, delivered to the students online and face-to-face, came in a variety of media that needed to be read/viewed/solved in myriad ways. Teams had to study, synthesise and report their findings to the other members of the Task Force in order to collectively build evidence and hypothesise about the potential solution. Our intention was to leave unanswered questions to allow students the opportunity to construct alternative pathways within the mystery. The project design incorporated online lectures,

\footnotetext{
${ }^{1}$ The first mystery centered on the discovery of an abandoned alien spacecraft and the subsequent search for the missing alien; the second mystery was to solve an environmental disaster related to a city's water supply; and the final mystery was a criminal investigation into the theft of a valuable piece of art. All three mysteries integrated literacy, mathematics, science, geography and information and communications technology. All three mysteries were possible but implausible.
} 
discussion forums, wikis and web pages integrated into the university's Blackboard learning management system.

Our students often struggle with the demands of group work because of personality clashes and differing work ethics, geographic dispersion, timetables and differing work/study arrangements. To assist with some of these challenges, each team was provided with its own private wiki space where they were asked to share the knowledge they were building, to post and modify their findings, hypothesise after each phase in the investigation, and to use the space to organise and allocate responsibilities within their team. The intent was to use technology authentically, to provide a space where students could collaboratively build knowledge in ways that did not rely merely on face-to-face interactions.

In the process of developing this simple environment, we were active in learning more about the technology. Reflecting on the nature of the first mystery gave rise to thoughts about what else might be possible if we could overcome the limitations of our own technical skills. The University's Education Media Group offered us expertise in multimedia production, graphic design, web development, video production, and photography. They would transform some of the dreams in our heads to innovative realities. The result in the second mystery was a far more sophisticated online environment, complete with Flash interactive learning objects, images, podcasts, videos, a custom made wiki, blogs and a discussion forum that allowed people from outside the university to participate, all delivered in a slickly-designed web based 'desktop' interface. A key feature of the new online environment was a content management system that allowed us to deliver different 'evidence' and clues (content) to different individuals and groups of individuals.

\section{Methodology}

While developing the blended learning approach, there was need for collaborative, systematic and comprehensive feedback as part of a three year Participatory Action Research (PAR) project. This involved us planning, acting, reflecting, evaluating, and initiating additions and improvements which have assisted in expanding and strengthening the blended inquiry-based mystery over time (Burns, 1999; Kemmis \& McTaggart, 1988). As a process-oriented and collective approach, PAR helped us to contexualise our research knowledge by monitoring our teaching and students' learning over time, as well as assisting us to make informed decisions about change. We understood the value of PAR as appropriate for carrying out classroom-based research. This methodology also assisted the development of skills of observation and critical reflection in and upon our practice with a view towards improving our teaching and learning. The approach used can usefully be applied to many aspects of classroom practice such as curriculum development, teaching and learning methods, strategies and assessment (Hopkins, 1993; Kemmis \& Mc Taggart, 1988; Zuber-Skerritt, 1993). The research was intended to enable all participants to collect, analyse data and eventually transform their practice. The students' investment was to discover more effective ways of using technology to better their teaching.

The Participatory Action Research undertaken took the form of opening up a pedagogical space for ongoing dialogue and critical reflection. By engaging in role-plays, lecturers and pre-service teachers become members of two different worlds simultaneously: the learner and the teacher. Boal (1995) described this state of being as "metaxis." In this state, the participant can better understand "real life" through the nexus between the imagined and the real. This opens up a dialogical space of possibilities for change to occur from routine, unexamined practices.

\section{Data collection and analysis}

Data was collected in weekly planning meetings over the three years of the project and extensive 
debriefings amongst teaching staff during and at the end of each mystery. Using professional journals teaching staff recorded weekly reflections that related back to the project's aims, capturing students' reactions and responses to the pedagogies we adopted and the technological environment in which they were immersed. We recorded our joys and frustrations with the technology and our perceptions about the strengths and inadequacies of our pedagogical approaches.

Data was also collected from student feedback in classes and in their normal subject evaluation surveys. Each year a series of online discussion forums were established seeking student reflections on their initial reactions to the subject, the disruptive pedagogies being used, the role that ICT played in the subject, the use of role play, cooperative learning, and higher order thinking. Student reflections prepared as part of assessments were also collected. A series of focus groups were held with students participating in the subject at the end of the academic year. Students and teaching staff had open conversations about the positive and negative aspects of the subject, its usefulness to them as teachers and the role that technology played in the subject. Focus groups also explored new ideas to refine future mysteries and their implementation.

In keeping with the principles of PAR, data was analysed each year in terms of the initial project aims. Common themes based on the aims were identified. Multiple passes of the data were made as new themes emerged from the analysis. New themes emerged about issues that hadn't been considered initially. Data from each mystery was also evaluated to better inform and support planning of the following year's mystery, to identify where additions or alterations to the mystery were required and initial aims strengthened and refined.

\section{Findings}

Initially it was felt that we had created an engaging technology-rich environment that would disrupt traditional modes of teaching and learning and would support our pedagogical beliefs. However, as we implemented each mystery, tensions arose between our intentions with the technology and the realities. These tensions provided learning opportunities to re-examine and strengthen subsequent approaches. The findings with respect to the aims, stated earlier, often overlap as each finding impacted on the others.

\section{Engagement in learning}

A central aim for redesigning our $2^{\text {nd }}$ year subject was to reignite and further engage in our university students' learning. Utilising Coates' (2007) aspects of engagement we built the subject being mindful of it comprising:

- $\quad$ active and collaborative learning;

- $\quad$ participation in challenging academic activities;

- formative communication with academic staff;

- $\quad$ involvement in enriching educational experiences;

- $\quad$ feeling legitimated and supported by university learning communities.

At the outset of each mystery, many students' expectations were challenged. There was heightened interest in what they were experiencing and student engagement, at least initially, appeared high. The following example typifies students' initial responses: 
At the beginning of this semester, I was really intrigued and excited about what we were going to be doing throughout the first 5 weeks of this subject. (Kara)

Student attendance, while not compulsory, was another measure of engagement and it remained consistently high throughout each mystery. The students felt the need to attend in order to receive new information and help other team members make sense of the new clues unfolding. High attendance was greatest in the third mystery when we increased the emphasis on physical clues being distributed face-to-face rather than all clues being delivered online as was the case in the first two mysteries.

However, the initial excitement that our pre-service teachers expressed in the sophisticated online environment we developed in the second mystery soon gave way to expressions of frustration and disenchantment as the technology failed to work. Key areas of the online environment were not ready or its full functionality was not available. Anxiety levels rose. Students revealed comments such as:

It was very difficult when we initially started the subject as we had dilemmas with the technology and the wikis (Sean)

The teaching staff shared the students' frustrations with the failure of the technology, However, in the next mystery, the technical issues were largely overcome and did not create the barrier they had in the previous year. Engagement was restored.

Unexpectedly, lecturer engagement was also high. We looked forward to each class, our teaching was reinvigorated and we were excited to employ new practices and to learn from collaborating with colleagues from differing disciplines. From Lecturer 1's Professional Journal:

I haven't worked this hard on a subject in years yet I am enjoying almost every minute of it (when the technology is working). I'm also learning to teach more effectively. There comes a time in your teaching when you feel you are in command of your subject content and you are able to share it effortlessly. I now realise how dangerous this feeling can be. My engagement with this course comes from the myriad challenges I face moment by moment-just floating in a sea of unknowns, often dangerous risk-taking and the exciting collaboration with colleagues outside my discipline.

\section{Disrupting the norms of traditional schooling}

One of our key aims was to model a risk-taking pedagogy; one that focused on student-centered collaborative inquiry and problem solving, rather than on transmissive pedagogies and entrenched ways of "doing school." For example, we decided not to provide the expected detailed subject outline and schedule as we felt this would remove the sense of "mystery" that needed to unfold. Instead, we asked our students to trust us. Some did, as illustrated in this sample comments:

This online introduction to the course is so much more exciting then the normal mode with the first lecture and tute. We have been listening to people tell us that virtual learning is exciting and a new method of teaching students to learn independently however this is the first time we are experiencing it ourselves. I think it's REALLY exciting and also will keep everyone tuned in over the next few weeks. I am looking forward to the clues and the rest of the mystery. (Pam)

However, for some students, the lack of detail regarding the subject outline was a cause for initial anxiety, as typified in this comment:

I am feeling uncomfortable and nervous as we have to wait anxiously for the information presented as the 'mystery unfolds'. This is definitely going to put me out of my comfort 
zone as I like to have all the information before plunge in. (Alicia)

Underlying these concerns was the perception of learning as a fixed set of topics they were expected to learn and to regurgitate in assignments in order to obtain high marks, as suggested in the following two comments:

I am so familiar with knowing exactly what I expect to get out of a course and what criteria I need to abide by in order to achieve good marks and the acquired knowledge intended. However this course was different, which was refreshing. (Mary)

The use of role play as a major pedagogical strategy also challenged some students, illustrated in the following:

I found that as the time wore on I felt a little silly continuing with the role play as not many others seemed to be into it. (Sally)

Despite the reluctance of some of our university students to actively participate in the role-play aspect of the subject, most perceived benefits from using such an approach with primary students Role playing allows us to be in a different dimension by taking on another person's character and role. With relation to the mystery where we are role playing certain characters and careers, we are taking on their knowledge and applying it to ours. Even though at times this could be difficult, incorporating role play in a classroom is great to get students thinking in a different viewpoint and seeing things from another persons view. (Kate)

Students in this subject were allocated to groups, rather than self-selecting their groups. For many this was a challenge, however, most students recognised the benefits of this approach as typified by Donna's comment:

Initially I found it a bit difficult to work with my team because we were all so different, not from the same group of friends and one of the girls I had never even seen before - let alone met! As we progressed though, I realised it was probably a good thing being just put into a group rather than choosing because it meant I challenged myself to get to know other people and I accept that we are always going to need to get along with people who bring forward different opinions, beliefs, work ethics and skills. (Donna)

\section{Integrating technology in purposeful, authentic and student-centered ways}

\section{Student- centered use of technology}

We started with the premise that our pedagogical innovation needed to model student-centered pedagogies and authentic use of technology. A central idea of student-centered learning is that students have greater control over choice of subject matter, learning methods and the pace of their learning (Gibbs, 1992). Herrington, Oliver and Reeves (2003) argued that authentic learning activities:

- $\quad$ have real world relevance;

- $\quad$ are ill-defined, requiring students to define tasks and sub-tasks;

- comprise complex tasks to be investigated over a sustained period;

- $\quad$ provide opportunities for students to examine the task from different perspectives; 
- $\quad$ provide the opportunity to collaborate;

- $\quad$ provide the opportunity to reflect;

- $\quad$ are integrated and applied across different subject areas and lead beyond domain-specific outcomes; and

- allow competing solutions and diversity of outcomes.

Our scenarios in all three mysteries met most of these accepted characteristics of authentic learning. Yet, there was little flexibility in the way the mystery unfolded since digital "clues" needed to be specified months before the scenario was implemented so they could be designed and produced by the web developers within strict timelines. The flexibility inherent in truly studentcentered learning environments was sacrificed so that the next set of pre-determined evidence could be delivered. Students therefore had limited choice in the direction or pace their learning took. We initiated an improvement by placing more emphasis on the critical and creative interpretations of how the mystery may have ended and less emphasis on recounting the facts of each investigation.

\section{Authentic use of technology - Information delivery}

The design and online delivery of the mystery led us to believe we could disrupt the ways in which subjects are traditionally delivered. We believed the online material was somehow different, but in reality we were still disseminating teacher-created and directed information. In the first mystery, technology was used simply as a delivery mechanism, which was in contrast to our espoused beliefs about how technology could and should be used. In the second mystery all clues, in the form of multimodal learning objects, were delivered to the students online. But we had fallen into the trap of "glitzing up" (Yelland, 2007) how we delivered information to our students, even when there were times when it would have been far more pedagogically sound to deliver clues face-toface. So much attention and time went into developing learning objects that we focused less on the important and more authentic use of technology such as the wiki space and discussion forums that pre-service teachers could use to collaboratively build knowledge through discussion, and build and test hypotheses. Our students reminded us of this in comments such as this:

I believe that to reduce the impact of technological problems affecting lessons, some of the clues should be given in hard copies like actual newspaper articles rather than the use of wikis and the internet 100\% of the time (Robbie)

We decided to make significant changes to the blended delivery in the third mystery. We used far more role-play and paper-based evidence for students to analyse. We also handed over control far more and got the pre-service teachers to conduct more peer teaching and take more responsibility for finding information.

\section{Authentic use of technology - Collaborative knowledge building}

A wiki was the main tool used to support collaboration within and between the teams. At predetermined points in each investigation, teams were asked to post hypotheses and conclusions on their wiki page, or solve problems that would lead to the next clue. At various points, teams were able to see other teams' wikis as a way of sharing ideas and of learning what was possible to create within the wiki environment. In the first mystery, we used a simple wiki. Students who had never heard of a wiki became familiar with its functionality and began to see the benefits of the collaboration it fostered, as illustrated in this student comment: 
Something that surprised me was the collaborative way my team worked in class but especially through the use of ICT and our team wikis. The way the wikis played a vital role in the whole investigation. I was surprised at the way I relied on the wiki, and the reliance that my team held on the wiki for communication, organising our multimodal text, to delegate roles and even to just generally see how each member was going and their individual contributions to the mystery (Sarah)

In the second mystery, the new wikis developed as part of the new online environment were not working until well into the investigation. This gave students time to develop other ways of communicating within their teams. Many preferred to use alternative and well-entrenched means of communication for the investigation - text, mobile phones, emails and face-to-face meetings, and Facebook:

Ifound alternatives to accessing the mystery from home such as sending emails instead of wiki posts. (Jane)

Our team also kept in touch using Facebook as we found it easier to communicate using this tool. (MengFei)

We also made assumptions that our students would know what a wiki was and how to use one. This was not a realistic assumption, despite the majority of our students being confident in using a wide range of digital technologies. The wiki became associated with "doing school" rather than being seen as a useful tool in itself. When students did use the wiki, many tried to use it in the same way they used Facebook, seeing each wiki page as a "wall" to which you post a comment, rather than seeing the page as a space you collaboratively build, compose and edit. Notes from Lecturer 2's reflections showed:

There is a strong reluctance to edit pages and put content on the pages. The preference in many teams is to establish a new page rather than change what is on an existing page, even if the content is focused on the same topic. There's also a strong preference to use comments rather than edit a page-are the students happier to read chronologically rather than summarise and synthesise? (Lecturer 2)

Once again, our expectations of what the technology might deliver and what actually happened were at odds with one another.

In the first two mysteries we analysed who made contributions to the wiki and found that the more technically competent and confident students were "taking the mouse" and doing most of the wiki work. This was not our intent. We wanted all participants to develop and build on their existing ICT skills. To improve this aspect, subsequently tasks were subsequently designed that required a different student to take the lead each week in adding to or modifying the wiki for their team.

\section{Transformative Learning}

It was our intention that the pre-service teachers would be able to experience a new way of learning and then transfer that learning to their future teaching practice. Transformative learning developed by Mezirow (1995) over three decades ago has evolved to describe how learners "reformulate the meaning of their experience" (Cranton. 1994, p. 22, emphases added). Centrality of experience, critical reflection, and rational discourse are three common themes present in Mezirow's theory (Taylor 1998). For learners to alter and then apply specific beliefs and attitudes, "they must engage in critical reflection on their experiences, which in turn leads to a perspective transformation” (Mezirow 1991, p.167, emphases added).

We continue to find that pre-service teachers experience difficulty looking back on their university 
learning experience with a critical lens and then applying it to the classroom. This was confirmed in the first year of the mystery when as a final assessment task students were asked how they would transfer this experiential learning to a primary classroom.

To assist them further, during the last two mysteries we attempted to spend more time in class and online in the discussion forum exposing our thinking as lecturers and the reasons behind our planning for the subject. We shared our beliefs that the opportunity for pre-service teachers to enact the content being covered in the subject under discussion meant that they could experience first hand some of what their students would experience. This allowed them to trust the experience far more. We also provided more opportunities to practise critical reflection. This assisted students' ability to transfer their learning. For instance, Huang-Lee relates the value of a team wiki in primary schools when she says:

Children can gather all the information that they have and collaborate between them all. The use of the wiki allows the contribution of all students and all students are able to apply their own spin and ideas on the investigation.

Ben's reflection below also typifies some of the transformational learning many students achieved.

Throughout the [subject], I was undecided about how I felt I was learning and what exactly we were covering by doing this investigation. However, now that it's over I can step back and look at what we actually covered and learnt throughout the process ... I started to realise that maybe there was educational value in what we were doing. This started getting me thinking about the ways in which I could structure a classroom in the future. I like the idea of involving students in an investigation that blends the lines of the curriculum.

Sadly however, because of our often sophisticated technology platform and designed interactivity in the mystery, the pre-service teachers were less able to envision ways to transfer those technological aspects to the primary classroom. As well, the sheer volume of technology used in the inquiry based mysteries made transferability to practical classroom use far less certain. Teachers would not have the time, the expertise or the available technology to make the mysteries solely a virtual reality.

For example, Fiona recognised some of the difficulties when she said:

One thing I've noticed during this subject is the amount of communication that is needed between team members. We might need to figure out another way for students to communicate - maybe through snail mail in the classroom? (Each group/student could have their own mailbox set up for other students to put their ideas/contributions into). If we are going to use this sort of learning in a classroom, we need to consider every eventuality when it comes to technology, as well as the students' access to the technology.

If learning is change then our mission must be to foster and reward ethical change in beliefs and practices.

\section{Conclusion}

Our initial aim was to design a university subject within a Teacher Education program that better responded to the needs of 21 st Century learners. The benefits of our approach were many. We successfully disrupted some of the norms and expectations of university teaching and learning in order to interrogate them further. Attendance was generally high at lectures and tutorials as students appeared eager to receive their next clues and anxious to solve the mystery. Discipline 
knowledge was bridged and appeared seamless. Students were immersed in the mystery, their work in teams had authentic purpose and they employed multimodal ways of knowing. As well, while students were taken out of their comfort zones this was undertaken in a safe and supportive environment. Lecturers and tutors were far less traditional in their approaches to university teaching often conducting interactive lectures in role with new evidence provided. An unexpected benefit was how the mysteries provided an enriching experience to the teaching team as we crossed disciplines, planning and teaching together. It was fun for most participants to engage in the mysteries but not always "hard fun."

The challenges allowed us to better understand how to modify our approach in subsequent years. Our students found it difficult to transform their experience to their teaching practice as they would not have the available technologies. As well, the technology often directed the subject of the mystery.

Much of the focus of current learning and teaching places technology at the forefront. Laurillard (2002) warned us that decisions about educational technology should be driven by teaching aims rather than technology for its own sake. While it is essential to reform university teaching, we are cognisant of the need to be critically selective and thoughtful about what technology is used and how it is used. We are also aware of how much control we are prepared to give over to our students and their readiness and willingness to take over the control. We embrace, and continue to respond to Postman's (1993) prescient statement that: "Most people see only what technologies will do but are incapable of imagining what they will undo” (p. 5, emphases added).

\section{References}

Angeli, C., \& Valanides, N. (2009). Epistemological and methodological issues for the conceptualisation, development and assessment of ICT-TPCK: Advances in technological pedagogical content knowledge (TPCK). Computers \& Education, 52, 154-168.

Boal, A. (1995). The rainbow of desire: The Boal method of theatre and therapy. London: Routledge.

Brown, D., \& Warschauer, M. (2006). From university to the elementary classroom: Students' experiences in learning to integrate technology in instruction. Journal of Technology and Teacher Education, 14(3), 599-621.

Coates, H. (2007) A model of online and general campus-based student engagement. Assessment and Evaluation in Higher Education. 32(2), pp. 121-141.

Cranton, P. (1997). (Ed.). Transformative learning in action: Insights from practice. New Directions for adult and continuing education No. 74. San Francisco, CA: Jossey-Bass.

Drake, S. M., \& Burns, R. (2004). Meeting standards through integrated curriculum. Alexandria, VA: Association for Supervision and Curriculum Development.

Ertmer, P., \& Ottenbreit-Leftwich, A. T., (2010). Teacher technology change: How knowledge, confidence, beliefs and culture intersect. Journal of Research on Technology in Education, 42(3), 255-284.

Fishman, B. \& Davis, E. (2006). Teacher learning research and the learning sciences. In R. K. Sawyer (Ed.), Cambridge handbook of the learning sciences (pp. 535-550). Cambridge: Cambridge University Press.

Gibbs, G. (1992). Assessing more students. Oxford: Oxford Book University.

Gosper, M., Green, D., McNeill, M., Phillips, R., Preston, G. \& Woo, K. (2008). The impact of web-based lecture technologies on current and future practices in learning and teaching. Australian Learning and Teaching Council. Retrieved from http://www.cpd.mq.edu.au/teaching/wblt/overview.htm 
Gump, S. E. (2004). Keep students coming by keeping them interested: Motivators for class attendance. College Student Journal, 38, 157-160.

Herrington, J., Oliver, R. \& Reeves, T.C. (2003). Patterns of engagement in authentic online learning environments. Australian Journal of Educational Technology, 19(1), 59-71.

Hopkins, D. (1993). A teacher's guide to classroom research. Buckingham, UK: Open University Press.

Jonassen, D., Howland, J., Marra, R. \& Crismond, D. ( 2008). Meaningful learning with technology $\left(3^{\text {rd }}\right.$. ed.), Upper Saddle River, NJ: Pearson.

Kemmis, S., \& McTaggart, R. (2005). Participatory action research: Communicative action and the public sphere. In N. Denzin and Y. Lincoln (Eds.) Handbook of Qualitative Research (3rd Ed.) (pp. 559-604). Thousand Oaks CA: Sage.

Laurillard, D. (2002). Rethinking university teaching - A framework for the effective use of educational technology. London: Routledge.

Mezirow, J. (1995). Transformation Theory of Adult Learning. In M. R. Welton (Ed.), In defense of a lifeworld (39-70). New York: SUNY Press.

Nolan, P., \& McKinnon, D. (2003). Enhancing the middle in a New Zealand secondary school: Integration, experiential learning, and computer use. International Journal of Educational Reform, 12, 230-243.

Otero, V., Peressini, D., Meymaris, K., Ford, P., Garvin, T., \& Harlow, D. (2005). Integrating technology into teacher education: A critical framework for implementing reform. Journal of Teacher Education, 56(1), 8-23.

Postman, N. (1993) Technopoly: The surrender of culture to technology, New York: Vintage Books.

Prensky, M. (2001). Digital natives, digital immigrants. On the Horizon, 9(5), 1-6.

Salopek, J. J. (2003, June). Going native: Cross the generation gap by learning to speak. $T+D, 57$. Retrieved from http://findarticles.com/p/articles/mi_m0MNT/is_6_57/ai_103136254/

Taylor, E.W.(Ed). (1998). A critical review. ERIC Clearinghouse on Adult, Career, \& Vocational Education (Information Series No. 374).

Yelland, N. (2007). Shift to the future; Rethinking learning with new technologies in education. New York: Routledge.

Zuber-Skerritt, O. (1993). Improving learning and teaching through action learning and action research. Higher Education Research and Development, 12, 45 - 57.

Copyright $@ 2012$ Gloria Latham and Nicky Carr 